\title{
Chapter 6: Russia's Regional Free Trade Agreements and Agri-Food Trade After 2014
}

\author{
Christel Elvestad and Tatiana Isachenko
}

\section{INTRODUCTION}

Recent years have witnessed the rise of populism and economic nationalism. International trade in general is attacked from the political left and political right. In the United States, the Trump administration has led the way in attacking free trade. The political left points to rising inequality, loss of jobs, and stagnant incomes for the working class. The political right points to high trade deficits. On the political left, critics argue that trade agreements favour the interests of corporations over workers. On the political right, critics maintain that agreements put international interests above national interests. ${ }^{1}$ Both sides blame trade. A contrary trend, however, has been an increase in the popularity of regional trade agreements, (RTAs). ${ }^{2}$ Some RTAs are narrow in range, focusing mainly on reducing tariffs for specific types of goods. However, modern RTAs often

C. Elvestad $(\bowtie)$

Nord University Business School, Bodø, Norway

e-mail: christel.elvestad@nord.no

T. Isachenko

Department of International Economic Relations and Foreign Economic Ties, MGIMO University of the Ministry of Foreign Affairs, Moscow, Russia

(C) The Author(s) 2022

S. K. Wegren and F. Nilssen (eds.), Russia's Role in the Contemporary

International Agri-Food Trade System, Palgrave Advances

in Bioeconomy: Economics and Policies,

https://doi.org/10.1007/978-3-030-77451-6_7 
include a wider range of areas such as trade in goods, services, investments, public procurement, competition, and intellectual property rights. There are over 300 RTAs in force and there is an expanding worldwide RTA network.

Russia started to negotiate regional free agreements later than other countries, but since 2015 it has been an active player. This chapter is important because although Russia has pursued a specific variant of food security since the 2008-2010 period, a variant that emphasises trade protectionism, the story is more nuanced than commonly portrayed. While it is true that food self-sufficiency and import substitution have dominated Russia's food policies since 2014, trade patterns show not a withdrawal from international food markets but rather an adjustment and recalibration of partners. Thus, this chapter sheds light on how Russia's regional trade policies and agri-food trade patterns have changed after the introduction of countersanctions in 2014.

The purpose of this chapter is to: (1) examine Russia's regional trade strategies as the driving force of Eurasian regional trade integration, focusing on agri-food policies as a key component; (2) review Russia's free trade agreements through the Eurasian Economic Union; and (3) access the role of agri-food trade in signed and upcoming agreements, as well as how food trade relations have changed in the period after sanctions were introduced in 2014 . The final section provides a look into the future of Russia's free trade agreements and agri-food trade.

\section{International ConteXt}

Regional and preferential economic cooperation has attracted increasing attention as free trade agreements have expanded in number and scope and become an important part of the global trading system. ${ }^{3}$ The proliferation of RTAs is important for most countries regardless of their level of economic development. Because RTAs allow for more favourable terms of trade, the share of global trade between members of RTAs has been steadily growing in recent decades.

In addition to an increase in the number of RTAs, from about 50 agreements in the 1990s to over 300 agreements in 2020, RTAs are becoming more complex. ${ }^{4}$ Modern RTAs often go beyond tariff reduction in certain sectors and products, instead covering a wide range of policy areas. There have been a stronger emphasis on reducing and removing non-tariff barriers to trade such as unnecessary or overly 
bureaucratic technical regulations and procedures that can hinder or even stop trade completely. ${ }^{5}$ There is also a growing trend for RTAs to not just liberalise trade in goods, but also to liberalise services, investment, and areas such as intellectual property rights, government procurement, competition policy, and issues like environmental and labour standards. ${ }^{6}$

Furthermore, RTAs can be concluded between countries located within or across regions (inter- or intra-regional agreements). Bilateral agreements are still common, but RTAs can also include a multiple countries, for instance the Trans-Pacific Partnership (TPP 11) or the Regional Comprehensive Economic Partnership (RCEP). ${ }^{7}$ In some cases, the agreements are signed between regional trade blocks, for example between the European Union (EU) and the Southern Common Market encompassing Brazil, Argentina, Uruguay, and Paraguay (MERCOSUR). ${ }^{8}$ Furthermore, regional trade blocs often coordinate at the multilateral level to try to increase their influence in relevant international organisations. For instance, the EU has suggested a comprehensive approach to push forward modernisation of the Word Trade Organization (WTO). ${ }^{9}$

Why do countries sign RTAs? The classic answer from the economic literature is the benefit of net welfare gain that such trade agreements provide. By removing or reducing trade barriers, transaction costs are lowered and economic growth through internationalisation can be realised. The international political economy literature provides an analytical framework with four categories of motives behind RTAs, following a political-economical dimension and a domestic-international dimension.

The first category 'International Economic Motives' refers to the use of RTAs as a strategy to accommodate and shape the international environment, making it fit the country's economic ambitions in the international arena. Since RTAs provide for better terms of trade, it gives a competitive edge and potential 'first mover' advantages. Another important motive can be the need to cover a new issue that is missing in WTO/multilateral negotiations. ${ }^{10} \mathrm{~A}$ negative view is that it is a mistake to put all efforts on new free trade agreements instead of focusing on multilateralism and thus supporting the World Trade Organization. ${ }^{11}$ However, to negotiate RTAs can alternatively be viewed as a constructive response to the lack of progress at the multilateral level. RTAs may not pose a threat but may function as building blocks of trade liberalisation to be multilateralised at a later stage. ${ }^{12}$ The typical example of this is the desire to include investment in RTAs, since an agreement is still lacking in this area at 
the multilateral level. Another variant of international economic motives behind RTAs is the desire to extend domestic reforms to the international level using RTAs as reform anchors to test and benchmark reforms on a wider scale of economic integration. ${ }^{13}$

A second category, 'International Political Motives', refers to ambitions to create new coalitions or to strengthen existing ties between countries. Sometimes economic reasons are not decisive and regional agreements arise as a result of politically motivated efforts emphasising the geographical or historical characteristics of the relationship. For instance, the initial motivation of the United States under former President Obama was to make the Trans-Pacific-Partnership (TPP) the centrepiece of its strategic axis to the Asia-Pacific region. ${ }^{14}$ In other words, there can be a strong geopolitical motivation behind RTAs, emphasising and strengthening relationships between countries in and across regions. Furthermore, actors at the national level will try to influence RTA negotiations to fit their interests, and negotiators will try to absorb and take into consideration what outcomes can be accepted by domestic interest groups. ${ }^{15}$

A third category 'Domestic Economic Motives' refers to the quest for better market access for goods and services in order to satisfy the interests of national competitive industries. A classic motivation is to use RTAs as an instrument to promote its export-oriented sectors by opening relevant export markets. In other words, RTAs are used to liberalise trade in order to meet national trade interests.

The fourth category, 'Domestic Political Motives', on the other hand, refers to the use of RTAs in a way that is designed to maintain barriers or even put up new barriers to trade in order to defend national trade interests. A way to protect sectors that are not competitive is to treat the entire sector or specific goods as off-limits to liberalisation in RTAs. Typically, this type of protectionist strategy restricts agricultural concessions in RTAs. Agri-food is a so-called sensitive sector for many countries and as a result, trade liberalisation in the agricultural sector is more limited. ${ }^{16}$ Agriculture has only undergone one round of negotiations through the Uruguay Round the WTO. The Doha Round, started in 1997, was supposed to deal with agriculture but negotiations ended in 2008 and never restarted, thereby leaving agricultural tariffs generally high. ${ }^{17}$ The lack of agreement on agricultural goods is important because generally RTAs can help lower trade tariffs and barriers. We see that the share of global agri-food trade between countries with RTAs rose from about 20 percent in 1998 to nearly 40 percent in $2009 .^{18}$ 
Thus, RTAs reflect both domestic and international interests, and for each of the countries involved economic and political interests can come into play. Furthermore, the interests between the negotiation parties may coincide or be contrary to each other, making negotiation of RTAs a complex balancing act. Regarding Russia, one may discern elements of each of the four categories of motives, although during 2014-2018 the primary impulses have been domestic economic and domestic political. Starting in 2019, however, international economic and political motives have gained in importance. The earliest international motivations, however, may be traced to the creation of the Eurasian Economic Union (EAEU) to which we turn below.

\section{Russia AND THE EAEU}

This section examines Russia's role as the dominant partner and driving force of Eurasian regional integration. Agri-food policies have been a key component of Russia's trade strategies. One of the most notable features of Russia's modern trade policy is the search for the best possible model of regional partnerships. ${ }^{19}$ During the last decade, Russia has tried to revive integration projects with the Commonwealth of Independent States (CIS), as well as to sign trade agreements by drawing from best practices in international trade relations.

In 1994, CIS countries took measures to transition to a common free trade regime to ensure stability in the region. However, the parties failed to agree on a general list of exemptions. Therefore, the 1999 'Protocol on Amendments and Additions to the Agreement on the Establishment of a Free Trade Area' allowed for temporary exemptions from the free trade regime on a bilateral basis. Starting from the early 2000s, Russia initiated negotiations on a new CIS free trade agreement which was finally ratified in 2012 by Russia, Belarus, Kazakhstan, Armenia, Kyrgyzstan, Tajikistan, Moldova, and Ukraine. ${ }^{20}$ This phase of post-Soviet integration has been labelled a case of 'holding-together regionalism' of countries originally forming a single political entity struggling to find an effective form of cooperation. $^{21}$

The establishment of the Eurasian Economic Union in January 2015 brought together Russia, Belarus, Kazakhstan, Armenia, and Kyrgyzstan (see Chapter 8 for more institutional detail). Prior to the establishment of the EAEU, Russia, Belarus, and Kazakhstan formed a Customs Union that existed during 2010-2011. ${ }^{22}$ A Single Economic Space replaced the 
Customs Union during 2012-2014. The Eurasian Economic Treaty was signed in May 2014 which became effective in January 2015, thereby bringing the EAEU into existence. By design, the EAEU is a type of regional integration, featuring free trade between the member states, a common external tariff and suppression of internal customs controls (Customs Union), and further integration into a single market for all the 'four freedoms', for goods, services, labour, and capital. In fact, however, the EAEU has some features of an FTA and some of a Custom's Union. ${ }^{23}$

That said, there are several shortcomings in the EAEU. ${ }^{24}$ One problem is that the Eurasian Economic Commission as the executive body and the Supreme Eurasian Council as a legislative body adopt and approve decisions, but both bodies have little power to regulate controversial situations or settle disagreements between members. This situation points to the fact that Russia wanted to form the Union in order to integrate post-Soviet states, but having done so, does not appear committed to making the organisation work and certainly is not willing to cede much sovereignty to the Union. ${ }^{25}$

A second problem is disagreement on several key issues which brings to light the limited ability to resolve intra-EAEU disputes among EAEU members. Armenia and Belarus disagreed with Russia about gas transportation prices within the EAEU. ${ }^{26}$ In 2014, Belarussian President Alexander Lukashenko did not support Russia's position during the Ukrainian crisis, for example, refusing to recognise Russia's annexation of Crimea, and for the next several years the two nations engaged in a socalled 'milk war'. The contested situation after the presidential election in Belarus in August 2020 also created tensions among EAEU members. Armenia's recent doubts about participation in the EAEU further complicate the integration process, despite the fact that the most of Armenian agricultural exports are directed to Russia. ${ }^{27}$

A third area of concern encompasses carry over effects from Russia's 2014 food embargo against the West. Several examples are discussed. First, during the formation of the Customs Union between Russia, Belarus, and Kazakhstan, negotiations on free trade agreements with foreign countries outside the CIS were subject to coordination with Customs Union partners. Since the creation of Eurasian Economic Union in 2015, all trade agreements are to be signed on behalf of the block. However, before 2014, Russia negotiated free trade agreements with a wide range of partners. But most of those negotiations were either frozen 
or suspended or did not enter an active phase, which means that they never rose to the level of including other EAEU members.

Second, the legal basis for economic relations between the EU and Russia is the Partnership and Cooperation Agreement (PCA), which was originally signed in 1997 and ran for ten years. It expired in 2007 and was renewed annually after then. In 2007 the EU and Russia entered into negotiations on a New Agreement. Russia proposed the creation of a free trade area but this idea was not embraced by the EU. ${ }^{28}$ The New Agreement was to provide a comprehensive framework for bilateral relations and would have been built on the basis of WTO rules and would have included stable, predictable, and balanced rules for bilateral trade and investment relations. Negotiations started in 2008, but they were stopped in 2010 because no progress was made in the Trade and Investment part. $^{29}$ Following the 2014 Ukrainian crisis, the negotiations were suspended. Since 2014, the relationship between Russia and the EU are sporadic and fragmented. The contact between the parties should have be transferred to the EAEU level, but the EU has not been ready to accept this position and deals with EAEU member countries on a bilateral basis. ${ }^{30}$

Third, there were eleven rounds of negotiations between The European Free Trade Association (EFTA) and Russia, Belarus, and Kazakhstan since 2011, but these negotiations were suspended in March 2014 over the Ukrainian crisis. ${ }^{31}$ There have also been several attempts to negotiate preferential terms of trade with countries in the Asia-Pacific Economic Cooperation (APEC), like with New Zealand. The access to New Zealand as a part of the APEC market was very important for Russia, but the agreement faced opposition from Belarus who believed that free access for New Zealand products to the EAEU market and the Russian market would put its agricultural exports at risk. The negotiations with New Zealand started in 2013, but they were suspended in 2014 because of the West's sanctions and Russia's countersanctions.

Fourth, the Ukrainian crisis of 2014 and Russia's countersanctions led to the banning of food products from the United States, the EU, Canada, Australia, Norway, Iceland, Liechtenstein, Albania, and Montenegro, including meat, fish, milk, vegetables, fruits, and nuts. Russia's countersanctions have been extended several times and in late 2021 were extended through 2022. Russia's food embargo has led to a reduction in food imports in general as consumers buy more domestic food products; and agri-food trading partners have changed. Domestic food products 
now account for more than 80 percent of was is sold in retail outlets, compared to 60 percent before the sanctions regime was implemented in 2014. ${ }^{32}$ However, when countersanctions were introduced in August 2014, Belarus and Kazakhstan refused to join the ban against Western products. ${ }^{33}$ As a result, Russia's import substitution programmes were implemented exclusively in Russia, outside the Eurasian context, and without any use of the resources and capabilities of the EAEU countries. Belarus was, for instance, not in a position to participate in the import substitution programmes, even though Belarus products have traditionally had been approved for import substitution to Russia. ${ }^{34}$

The upshot is that at present, there is no comprehensive agricultural policy among EAEU members, although they do have a common agreement on tariff-rate quotas (TRQs) for meat imports into the EAEU. ${ }^{35}$ Further, there is evidence of movement towards greater cooperation and coordination. When speaking about agricultural policy among EAEU members, Russian President Vladimir Putin stated that, 'We foresee large reserves in expanding mutual supplies of food. It is hardly logical to import vegetables, fruit, milk, and meat products from distant countries, placing orders with foreign suppliers when our own producers are ready and willing to work and enter a common Eurasian market with products that are not inferior and, in fact, often superior in quality'. ${ }^{36}$

In August 2020, the Eurasian Economic Commission and Russia's Ministry of Agriculture discussed the creation of a single internal market for agricultural products. This integration project is in its infancy, aiming to foster cooperation in agricultural science, training of agricultural workforce, and exchange of experience and knowledge in agriculture. There is also in the works a treaty on creating a single market for organic agricultural products within the EAEU. The purpose of the proactive approach towards a common agricultural policy for organics is to maximise export potential to meet growing global demand. ${ }^{37}$ The heads of the EAEU states created 'The Council for EAEU Agro-Industrial Policy' to ensure effective interaction between the ministries of agriculture of the member countries and to coordinate their policies. In addition, the Council has discussed food security in response to the coronavirus pandemic. A comprehensive act is being drafted that will define general principles and approaches to ensuring food security for the EAEU countries. The minister in charge of the industry and agricultural sector in the Eurasian Economic Commission, Artak Kamalyan, noted that, in the context of the coronavirus pandemic, issues of stable saturation of the market with 
food products are becoming increasingly acute and urgent. In addition to maintaining the stable and uninterrupted functioning of the Union's internal agri-food market, we must join our efforts and take concerted action to find new export niches'. ${ }^{38}$

\section{Trade Agreements}

Within the framework of the EAEU, Russia has concluded free trade agreements with a number of countries: Vietnam, Serbia, Iran, and Singapore, with other negotiations ongoing. The first such agreement has been in effect since October 2016 between the EAEU and Vietnam, and in the first year about half of all import custom duties were set to zero. Within ten years, 90 percent of goods will be duty-free. For trade in general, Russia has not been able to increase its exports to Vietnam as much as Vietnam increased its exports to Russia, and thus Russia runs a trade deficit with Vietnam. ${ }^{39}$

The FTA between the EAEU and Serbia was originally signed in October 2019 and it was ratified by Russia's Federation Council in October 2020, with the agreement taking effect in November 2020. ${ }^{40}$ The FTA with Serbia fully harmonises trade terms with Russia, Belarus, and Kazakhstan and establishes the same terms of trade for agriculture with Armenia and Kyrgyzstan. However, Serbia excluded items like some sugar, tobacco, and undenatured alcohol items and some tariff quotas like for processed cheese and some spirits and tobacco products for the EAEU countries except Russia. The EAEU excluded some poultry items, processed cheese, sparkling wine, undenatured alcohol, and tobacco items. Furthermore, EAEU will apply tariff quotas for some cheese, spirits, and tobacco products, but will allow a limited amount of these goods to be imported duty-free from Serbia.

In October 2019 a Temporary Agreement on Free Trade between the EAEU and Iran was signed. The temporary agreement with Iran was expected to be replaced with a permanent free trade agreement by the end of $2020 .{ }^{41}$ The FTA with Iran includes reductions on import duties on 360 Iranian commodities and 502 commodities from the EAEU. Concerning agri-food trade, Iran will reduce import duties on commodities such as beef, mutton, legumes, and vegetable oils. The EAEU gives trade preferences to Iran on products such as cheese, plant items, nuts and fruits, fresh vegetables, processed vegetables and fruits, confectionary, 
and bakery items. ${ }^{42}$ The EAEU-Iran agreement has benefited RussiaIran agri-food trade. In 2018, Iran was number eight on Russia's top list of export destinations for agricultural products. Unlike the United States and the European Union, Russia has not imposed sanctions on Iran and has aimed for buying up to 500,000 barrels a day of Iranian oil in exchange for Russian equipment and goods. ${ }^{43}$

In addition, a Framework Agreement on Comprehensive Economic Partnership between the EAEU and Singapore was signed in October 2019.4 ${ }^{4}$ Press coverage of the agreement noted that agreement with Singapore 'provides for duty-free trade in almost all the types of goods except for the list of sensitive items from the EAEU member states....[and] will also regulate the existing trade ties and will expand the opportunities for cooperation' ${ }^{45}$ The FTA with Singapore allows all goods from the EAEU countries to Singapore duty-free. After a transition period ranging from three to ten years depending on the product, 87 percent of goods from Singapore will be exempted from duties to the EAEU. Market access for food products is especially important to Singapore, as the country has no agricultural sector. But Singapore cannot supply the EAEU/Russian food market as it is fully dependent on food imports. It is interesting to note that Singapore has made substantial investments in the Russian agricultural sector by investing in grain manufacturing. ${ }^{46}$ A list of free trade agreements between the EAEU and other countries is presented in Table 1 .

Generally, Russia is shifting its attention to the East in the search for new FTA partners. ${ }^{47}$ Negotiations are ongoing between the EAEU and India, Egypt, Indonesia, Brunei, and Cambodia (see Table 2).

In addition, FTA negotiations have been opened with Israel. The ability to increase its influence in the Middle East has been one of Russia's motives for starting FTA negotiations with Israel, from which Russia will be the main beneficiary. According to Israeli Charge d'Affaires in Russia, the deal could be completed by the end of $2020 .{ }^{48}$ Since the collapse of the USSR, Russia and Israel have developed closer relations and not only in trade, indicated by Putin's visit to Israel in January 2020 during which Israeli Prime Minister Netanyahu referred to Putin as a 'great friend' and said that he and his wife are 'pleased to host you again at our home here in Jerusalem'. ${ }^{49}$ Another country in North Africa that is a long-term trading partner for Russia is Egypt (see Chapter 9), with whom negotiations for a FTA started in 2017. Although there is no official information about the negotiations, it is assumed that a traditional FTA is on the table. 
Table 1 EAEU-third country free trade agreements

\begin{tabular}{|c|c|c|c|}
\hline Trade partners & Type of agreement & Year/status & Comments on scope/coverage \\
\hline Vietnam & $\begin{array}{l}\text { Free trade } \\
\text { agreement-FTA }\end{array}$ & 2016 & $\begin{array}{l}\text { FTA including a wide range } \\
\text { of sectors/areas }\end{array}$ \\
\hline Iran & FTA & 2019 & $\begin{array}{l}\text { FTA limited in scope }(50 \% \\
\text { of mutual trade), interim } \\
\text { agreement until } 2021\end{array}$ \\
\hline Serbia & FTA & 2019 & $\begin{array}{l}\text { FTA including a wide range } \\
\text { of sectors/areas }\end{array}$ \\
\hline China & $\begin{array}{l}\text { Trade and Economic } \\
\text { Agreement }\end{array}$ & 2019 & $\begin{array}{l}\text { Non-preferential agreement, } \\
\text { focus on technical } \\
\text { regulations and Intellectual } \\
\text { Property Rights }\end{array}$ \\
\hline Singapore & $\begin{array}{l}\text { FTA } \\
\text { (Memorandum of } \\
\text { Understanding, 2016) }\end{array}$ & 2019 & $\begin{array}{l}\text { Investment, trade in goods } \\
\text { and services }\end{array}$ \\
\hline
\end{tabular}

Source EAEU, http://www.eaeunion.org/

Table 2 EAEU-third country free trade agreements and memoranda of understanding/FTAs under negotiation

\begin{tabular}{ll}
\hline Trade partner $(s)$ & Year/status \\
\hline India & MoU 2017, FTA negotiations \\
Israel & MoU 2015, FTA negotiations \\
Egypt & MoU 2016, FTA negotiations \\
Indonesia & MoU 2019, FTA negotiations \\
Cambodia & MoU 2016, FTA negotiations \\
Brunei & MoU negotiations \\
Peru & MoU 2015 \\
Chile & MoU 2015 \\
South Korea & MoU 2016 \\
Faroe Islands & MoU 2018 \\
Morocco & MoU 2017 \\
Cuba & MoU 2018 \\
Greece & MoU 2017 \\
Moldova & MoU 2017 \\
Jordan & MoU 2017 \\
Mongolia & MoU 2015 \\
Bangladesh & MoU 2019 \\
Thailand & MoU 2018 \\
Mongolia & MoU 2015 2019 \\
Argentine & MoU 2017 \\
Ecuador & \\
\hline
\end{tabular}

Source EAEU, http://www.eaeunion.org/ 
Even without a FTA, Egypt is a large purchaser of Russian wheat on an annual basis. In 2014 Egypt ranked third in dollar value for imports of Russian food exports, rising to second place in 2018 at more than \$2.1 billion USD. In November 2020, Russia received permission to export dairy and fish products to Egypt. ${ }^{50}$ Once a FTA is concluded it may be expected that the value of Russian agri-food exports will increase, perhaps challenging China for first place.

In addition to the ongoing negotiations with the aforementioned countries, there is a list of more than 20 Memoranda of Understanding (MoUs) with individual countries (see Table 2). The EAEU has also established MoUs with other trade blocks including ASEAN (2018), Mercosur (2018), the Andean Community (2019), the Pacific Alliance (2019), and the African Union (2019). MoUs are not binding international agreements, but declarations of intent to promote cooperation and increase trade and investment between the parties. A typical MoU includes areas of cooperation related to trade liberalisation and economic integration with specific chapters on issues like trade facilitation, customs, technical regulations, sanitary and phytosanitary measures, government procurement, and sector-specific provisions such as cooperation between the parties in the area of agriculture. All of the MoUs made publicly available by the Eurasian Economic Commission have specific sections on agriculture. Thus, liberalisation of agricultural trade is or will be an important part of the free trade agreements between the EAEU and these countries. We now assess the role of agri-food trade in current free trade agreements and how agri-food trade relations have changed after 2014.

\subsection{Agri-Food Trade}

Russia's list of top trading partners for agricultural imports and exports has changed considerably after 2014, a result of Russia turning away from the West. ${ }^{51}$ Regarding nations that exported agri-food products to Russia in 2014, the top ten list of countries included Belarus, Brazil, Ukraine, Germany, Turkey, China, Poland, United States, The Netherlands, and France. In 2018, Belarus was still number one, while China advanced from number six to number two on the list. The United States dropped out of the top ten between 2014 and 2018 (see Chapter 10). Ecuador, Indonesia, and Azerbaijan were newcomers to the 2018 list, but some European countries remained important agricultural suppliers despite Russia's countersanctions. For instance, even though the total 
value of Italy's agricultural exports to Russia has declined, Italy is still on the top ten list of countries supplying Russia with agricultural products. The reason is simply that there is a strong demand in Russia for Italian food products like wine, pasta, peeled and pulp tomatoes, and food oils, as well as other products not covered by Russia's countersanctions. ${ }^{52}$ The top ten agri-food exporting nations to Russia in 2014 and 2018 are shown in Table 3 .

Belarus, being on Russia's border and a former Soviet republic, has a long-standing trade relationship with Russia. Belarus accounts for a large percentage of Russia's milk and dairy imports, as much as 80 percent according to some calculations. In 2014-2015, the press in Russia humorously noted that Belarus had become famous for its seafood exports to Russia, even though the country is landlocked. For the Russian government, however, the serious issue was that Belarus served as a transit country for banned food products from the West, a fact that has been a sore point in the relationship since 2014. Russia has also accused Belarus of exporting more apples to Russia than it grows, implying that banned apples from Poland are being re-exported. The food trade relationship between the two has turned quite contentious, with periodic Russian bans on Belarussian milk and dairy, as well as Russia's Rossel'khoznadzor

Table 3 Top 10 countries of origin for export of agri-food products to Russia in 2014 and 2018 (million USD)

\begin{tabular}{clcclc}
\hline $\begin{array}{c}2014 \\
\text { Rank }\end{array}$ & Country & $\begin{array}{c}\text { Total agricultural } \\
\text { exports }\end{array}$ & $\begin{array}{c}2018 \\
\text { Rank }\end{array}$ & Country & $\begin{array}{c}\text { Total } \\
\text { agricultural } \\
\text { exports }\end{array}$ \\
\hline 1 & Belarus & $3,750.2$ & 1 & Belarus & $4,046.9$ \\
2 & Brazil & $3,593.9$ & 2 & China & $1,901.2$ \\
3 & China & $1,917.1$ & 3 & Germany & $1,409.4$ \\
4 & Turkey & $1,765.3$ & 4 & Brazil & $1,361.4$ \\
5 & The Netherlands & $1,571.6$ & 5 & Ecuador & $1,288.6$ \\
6 & Germany & $1,547.8$ & 6 & Turkey & $1,144.5$ \\
7 & United States & $1,394.3$ & 7 & Italy & $1,118.4$ \\
8 & Italy & $1,303.1$ & 8 & Indonesia & 896.8 \\
9 & France & $1,290.7$ & 9 & France & 850.7 \\
10 & Ecuador & $1,240.5$ & 10 & Azerbaijan & 526.2 \\
\hline
\end{tabular}

Source Author's calculations based on data from World Integrated Trade Solutions by the World Bank, https://wits.worldbank.org 
essentially insisting on control over Belarussian dairy factories. The reexport of banned food, unsafe additives, and counterfeit labelling has been major drivers behind Russia's push for digital labelling, truth in content labelling, and the tracing of the origins of products, including for grain. ${ }^{53}$

Turning to Russia's agri-food exports, by 2018 China had become Russia's number one export market (see Table 4). The importance of China for Russian trade will most likely continue to grow, as the Chinese economy is growing and the conflict with the West continues. ${ }^{54}$ Russia's turn to the East also has clear geopolitical motivations. Considering first total bilateral trade between Russia and China, we can see that it has grown significantly since 2014. In 2014, gross bilateral trade turnover between Russia and China was $\$ 90$ billion USD, which fell to $\$ 64$ billion USD in 2015 as a result of the downturn in the Russian economy. In 2017 total trade turnover rose to $\$ 87$ billion USD. In 2018, RussiaChina trade turnover exceeded $\$ 108$ billion USD, of which $\$ 56$ billion USD was Russian export. In 2019 Russia-China trade turnover surpassed $\$ 110$ billion USD, with Russia exporting nearly \$57 billion USD to China. In September 2019, the two countries signed agreements to increase bilateral trade to $\$ 200$ billion USD by 2024 . The agreements

Table 4 Top 10 destinations for Russian agri-food exports in 2014 and 2018 (million USD)

\begin{tabular}{clcclc}
\hline $\begin{array}{c}2014 \\
\text { Rank }\end{array}$ & Country & $\begin{array}{c}\text { Russia's total } \\
\text { agricultural } \\
\text { exports }\end{array}$ & $\begin{array}{c}2018 \\
\text { Rank }\end{array}$ & Country & $\begin{array}{c}\text { Russia's total } \\
\text { agricultural } \\
\text { exports }\end{array}$ \\
\hline 1 & Turkey & $2,372.9$ & 1 & China & $2,521.6$ \\
2 & Kazakhstan & $1,692.7$ & 2 & Egypt & $2,147.4$ \\
3 & Egypt & $1,386.6$ & 3 & Turkey & $1,860.9$ \\
4 & Korea & $1,192.0$ & 4 & Korea & $1,584.9$ \\
5 & China & $1,095.0$ & 5 & Kazakhstan & $1,524.6$ \\
6 & Belarus & $1,007.9$ & 6 & Belarus & $1,253.5$ \\
7 & Azerbajian & 772.3 & 7 & The Netherlands & 869.8 \\
8 & Netherlands & 649.7 & 8 & Iran & 791.3 \\
9 & Ukraine & 584.8 & 9 & Ukraine & 671.8 \\
10 & Georgia & 367.9 & 10 & Vietnam & 576.0 \\
\hline
\end{tabular}

Source Author's calculations based on data from World Integrated Trade Solutions by the World Bank, https://wits.worldbank.org 
encompass trade, economic cooperation, aviation, infrastructure, agriculture, and science and technology. ${ }^{55}$ For context, $\$ 200$ billion USD in trade turnover for these countries is not particularly large, but it does represent movement in the desired direction. In comparison, for example, American-Chinese trade turnover exceeded \$659.8 billion in 2018 and that was despite an ongoing trade war.

Russia's goal to increase its agri-food exports will be greatly enhanced if Russia continues to expand agricultural trade with China. Bilateral agricultural trade turnover between Russia and China has risen since 2014. Russian agri-food exports to China increased from less than $\$ 500$ million USD in 2000 to $\$ 1.1$ billion USD in 2014. An important milestone was reached in 2015 when the two sides signed an agreement that opened the Chinese market to Russian wheat and soybean. ${ }^{56}$ Agricultural trade began to increase steadily after 2015 . By 2018, total bilateral agricultural trade turnover reached about $\$ 4.5$ billion USD, with Russian exports totaling $\$ 2.5$ billion USD. In 2019 bilateral agricultural trade turnover exceeded $\$ 5$ billion USD for the first time. During the first ten months of 2020, Russia exported 3.7 million metric tonnes of agri-food products to China, valued at $\$ 3.2$ billion USD. ${ }^{57}$ The top ten list of nations to which Russia exports agri-food products is shown in Table 4.

Going forward, from the Russian perspective there are several opportunities to increase agricultural trade with China even without a FTA between the EAEU and China (see also Chapter 7). One opportunity to increase agricultural trade is the general economic development of the Russian Far East (RFE). From the Russian side, the Director of the Institute of Agricultural Market Conditions, Dmitry Ryl'ko, is quite optimistic that RFE can increase its food exports to China. He indicated that 'theoretically' soybean exports could expand to 1.5-2 million metric tonnes, up from 1 million tonnes that are currently exported from the region. While admitting that climatic conditions in the Russian Far East make the expansion of crop products modest, Ryl'ko maintains that the export of poultry and pork to China has a 'large potential' and good growth prospects, particularly of chicken feet and wings that are highly valued by Chinese consumers and for which Russia does not face much competition from Brazil or the EU. ${ }^{58}$

A second opportunity for Russian exporters is the enormous demand for food from China's urban middle class. No one knows exactly the size of China's urban middle class other than it is large and growing. At the low end, the Economist Intelligence Unit estimates that 10 percent of 
the population is middle class, or about 132 million people. ${ }^{59}$ At the high end, a different set of authors estimate that 50 percent of all urban households may be in the middle class, or more than 500 million people. ${ }^{60}$ Whatever its size, the gradual lowering of trade barriers following China's accession to the WTO was accompanied by rising income and living standards as well as changes in consumption habits. By 2013, China was importing nearly $\$ 26$ billion USD in agricultural products from the United States alone. ${ }^{61}$ During 2016-2018, China averaged more than 15 percent of total U.S. agricultural exports, more than any single country. ${ }^{62}$ Since then, China has become the world's largest agricultural importer by dollar value, with total annual agricultural imports reaching almost $\$ 140$ billion USD in 2017 and 2018. Thus, there is an enormous opportunity for Russian food exporters to increase their market share.

As Chinese consumers' incomes rise, their preferences gravitate towards higher-cost animal husbandry products and it is for that reason that Russian animal husbandry exports will be more valuable than crop exports. Pork is traditionally one of the most popular sources of protein in the Chinese diet and China is the world's largest producer and consumer of pork. In 2019, China's pork imports are estimated to have ranged between 3.1 and 3.3 million metric tonnes in 2019 with projections to reach 4.6 million metric tonnes in $2020{ }^{63}$ Against this context, Russia's pork production has increased substantially in the past decade, rising from 2.6 million tonnes in 2008 to 4.7 million tonnes in 2018 (all categories of farms). Within this overall rise, the number of pigs and pork production from households declined while pork production on corporate farms rose and in 2018 comprised 61 percent of total production. ${ }^{64}$

The opportunity for Russian exporters to increase their share in China's pork market is supported not only by rising Russian output but also by outbreaks of swine flu in China since 2016. In 2019 alone, the number of pigs in China contracted by more than 50 percent, from nearly 5 million pigs in January 2019 to fewer than 2.5 million pigs by late 2019; and pork production plummeted from 60 million tonnes to less than 30 million tonnes during that same period. ${ }^{65}$ That said, the opportunity created by falling domestic pork production in China is offset by shifting consumer preferences away from pork due to health concerns and more towards poultry and eggs. ${ }^{66}$

A final opportunity for Russia's exporters grows out of the U.S.-China trade war that during 2019 and into 2020 decimated American exports of soybean to China. Although Russia will not be able to fill the void 
completely, the Foreign Agricultural Service forecasts total Russian soy exports rising from 930 thousand metric tonnes in 2019/2020 agricultural year to 1 million metric tonnes in the 2020/2021 agricultural year, of which somewhere between one-half to three-quarters will be sold to China. ${ }^{67}$

In addition to food trade with China, trade with Vietnam has also expanded significantly. Above we noted that for total trade Russia runs a deficit vis-à-vis Vietnam, but if agri-food trade is considered the picture is more positive. Data from the World Bank show that there has been a sharp increase in Russia's agricultural exports to Vietnam after the FTA entered into force. ${ }^{68}$ In 2018, Vietnam was number ten on Russia's top list of export destinations for its agricultural products, (see Table 4). Prior to the FTA between Russia and Vietnam, agri-food trade was minimal, less than \$1 million USD a year in 2000 and there was not much improvement over time. Once the FTA was signed in 2016, however, Russia's agri-food exports to Vietnam increased quickly to $\$ 400$ million USD in 2017 , and since 2017 Russia's exports have surpassed the value of agri-food imports from Vietnam. Overall, Russia's agri-food exports grew from less than \$1 million USD in 2008 to almost $\$ 600$ million USD in $2018 .{ }^{69}$

\section{OutLOOK}

Taking a long view of Russia's agri-food trade policy and partners reveals a high degree of resilience on the part of Russia to changing geopolitical and geoeconomic conditions. Since the 1980s, Russia has gone through at least three iterations in trading partners since 1992. The first iteration was the change from a concentration on intra-bloc trade in the Soviet period-nations that would become CIS members in 1992 - to the development of trading relations with the West, most notably the EU, although that relationship was based neither on RTAs nor FTAs. During the 1990s agri-food trade with the EU overtook that with CIS members despite the latter having integrative advantages that continued from the Soviet period. The EU in particular became Russia's most important trading partner by volume and value, including agricultural and non-agricultural goods. That trade relationship continued during the 1990s up to 2014 .

The second iteration dates from the introduction of Russia's countersanctions against Western nations in August 2014. This period is marked by Russia's turn away from agri-food imports with the West and the EU, although Russia continues to export food to EU members. Flowing from 
the second iteration, a third iteration has been the expansion of trade partners and actual trade beyond the EAEU, beyond the EU, and encompassing new partners in the Middle East and Asia, especially China. This third iteration is characterised by RTAs and FTAs that were examined in this chapter. The composition of countries in the third iteration-nonWestern, some developing economies-is important because it reflects new political alignments. The composition also reflects the consolidation of trade relations with non-Western nations, which raises the question of not just when but whether Russia-Western trade can ever be revitalised. Further, the composition of trade partners in the third iteration holds importance for Russia's food security in that imports from developing nations are cheaper, thus benefiting consumers, but also may raise food safety and phytosanitary concerns, which obviously is not good for Russian consumers.

Across all three iterations, Russia has been an active participant in the global agri-food trade system as both an importer and exporter. Going forward, we do not expect Russia's role in the international food trade system to decrease in the years ahead. Although Russia is a relative latecomer to RTAs and FTAs, it has been active since 2014. Russian officials claim that the EAEU has received more than 50 proposals from various countries to establish or expand trade and economic relations. With a large number of MoUs, plus ongoing negotiations with Egypt, Ecuador, and Indonesia, we expect Russia to continue to expand its RTA profile.

In essence, Russia's trade resilience entails a three-part strategy since 2014. First, Russia has not severed relations with the WTO and continues to make periodic reports about its phytosanitary standards and other information as required by WTO rules. But agri-food trade with the West has diminished considerably, even to the point of irrelevance in the case of the United States (see Chapter 10). Second, Russia has increased the number of RTAs and FTAs that it participates in, whether temporary or permanent, preferential or non-preferential, and we expect the number to continue to grow. Third, Russia is committed to using the EAEU as an instrument to increase trade and various agreements, although it also is trying to increase bilateral ties as well. In this regard, analysts claim that the EAEU as well as EAEU external trade agreements primarily serve Russia's geopolitical agenda. ${ }^{70}$

All of the above is notable because a decade ago one would have expected that if Russia increased its RTAs and FTAs, it would be with the Western nations. Today, we know that is no longer true and Russia is 
putting most of its energy in developing trade with non-Western nations. While it is true that the EU is still Russia's most important trade partner as a recipient of Russia's exports (mainly energy), a free trade agreement is unlikely in the foreseeable future. At the same time, Russia's turn to the East holds major implications for its trade relations, the volume and direction of its agri-food trade, and the overall global geostrategic balance.

\section{Notes}

1. Kimberly Clausing, 'The Progressive Case Against Protectionism', Foreign Affairs 98, no. 6 (November-December 2019): 109-20.

2. Similar to free trade agreements, these types of agreements are referred to as trade preference agreements (PTAs), since trade liberalisation between the parties can go further without extending the privileges to other members of the World Trade Organization (WTO). Preferential free trade agreements can be bilateral or include more parties on a regional or intra-regional scale.

3. Claudia Hofmann, Alberto Osnago and Michele Ruta, 'The Content of Preferential Trade Agreements', World Trade Review 18, no. 3 (2018): 365-98.

4. For an updated overview of RTAs in force in 2020, see 'WTO Regional Trade Agreements Database', n.d. http://rtais.wto.org/UI/PublicMainta inRTAHome.aspx. Accessed 23 September 2020.

5. Timothy Josling and Stefan Tangermann, Transatlantic Food and Agricultural Trade Policy: 50 Years of Conflict and Convergence (Cheltenham, UK and Northampton, MA: Edward Elgar Publishing, 2015); and Edmond McGovern, International Trade Regulation (Exeter, UK: Globefield Press, 2008).

6. Rochini Acharya, 'Regional Trade Agreements: Challenges and Opportunities', International Trade Forum no. 4 (2018): 24-5.

7. Membership in the TPP 11 includes Australia, Brunei, Canada, Chile, Japan, Malaysia, Mexico, New Zealand, Peru, Singapore, and Vietnam. The agreement evolved from the Trans-Pacific Partnership (TPP), which never entered into force due to the withdrawal of the United States. The RCEP agreement is under negotiation between Brunei, Cambodia, Indonesia, Laos, Malaysia, Myanmar, the Philippines, Singapore, Thailand, and Vietnam, and five of their FTA partners-Australia, China, Japan, New Zealand, and South Korea.

8. Members of Mercosur, or the Southern Common Market, are Argentina, Brazil, Paraguay, and Uruguay. 
9. European Commission, 'European Commission Presents Comprehensive Approach for the Modernisaton of the World Trade Organization', Press Release, 18 September 2018. http://trade.ec.europa.eu/doclib/press/ index.cfm?id=1908. Accessed 6 November 2020.

10. Andrew G. Brown and Robert M. Stern, 'Free Trade Agreements and Governance of the Global Trading System', The World Economy 34, no. 3 (2011): 331-54.

11. Jagdish Bhagwati and Anne O. Krueger, 'US Trade Policy: The Infatuation with Free Trade Agreements', in The Dangerous Drift to Preferential Trade Agreements, eds. Jagdish Bhagwati and Anne O. Krueger (Washington, DC: AEI Press, 1995).

12. Richard E. Baldwin, 'Multilateralising Regionalism: Spaghetti Bowls as Building Blocks on the Path to Global Free Trade', The World Economy 29 (2006): 1451-518.

13. Bernard Hoekman, 'Open Plurilateral Agreements, Global Spillovers and the Multilateral Trading System', Working paper for the Bertelsmann Stiftung, 25 March 2020. https://www.bertelsmann-stiftung.de/fil eadmin/files/user_upload/MT_OPA_Paper_2020_ENG.pdf. Accessed 6 November 2020.

14. Council on Foreign Relations, 'What Is the Trans-Pacific-Partnership (TPP)?’, 4 January 2019. https://www.cfr.org/backgrounder/whattrans-pacific-partnership-tpp. Accessed 20 September 2020.

15. Robert D. Putnam, 'Diplomacy and Domestic Politics: The Logic of TwoLevel Games', International Organization 42, no. 3 (1988): 427-60.

16. See Christina L. Davis, Food Fights Over Free Trade (Princeton: Princeton University Press, 2003).

17. Kimberly Ann Elliott, Delivering on Doha: Farm Trade and the Poor (Washington, DC: Institute for International Economics, 2006), 3-9; Jennifer Clapp, Food, 2nd ed. (Cambridge, UK: Polity Press, 2016), 67-82.

18. OECD, 'The Impact of Regional Trade Agreements on Trade in Agricultural Products', OECD Food, Agriculture and Fisheries Papers no. 65, 2013. https://www.oecd-ilibrary.org/agriculture-and-food/the-imp act-of-regional-trade-agreements-on-trade-in-agricultural-products_ $5 \mathrm{k} 3$ xznkz60vk-en. Accessed 7 November 2020.

19. Tatiana Isashenko, 'The Trade Policy of Russia: Latest Developments and Main Priorities', Rivista di Studi Politici Internationzionali 80, no. 3 (2013), 347-60.

20. Azerbaijan and Turkmenistan did not sign the agreement, and the participation of Uzbekistan was initially regulated by a special protocol. Russia signed bilateral FTAs with Georgia, Armenia, and Serbia. 
21. Alexander Libman and Evgeny Vinokurov, Holding-Together Regionalism: Twenty Years of Post-Soviet Integration (London: Palgrave Macmillan, 2012).

22. See V. V. Rau, 'Russia in the Customs Union: The Agrarian Aspect', Studies on Russian Economic Development 24, no. 1 (2013): 77-83.

23. Veronika Movchan and Michael Emerson, 'The Eurasian Economic Union's Problematic Customs Union', 11 January 2018. Institute for Economic Research and Policy Consulting, Sweden. http://www.3dcfta s.eu/. Accessed 11 November 2020.

24. See Seljan Verdiyeva, 'The Eurasian Economic Union: Problems and Prospects', The Journal of World Investment and Trade 19, no. 4 (2018): $722-49$.

25. See Rilka Dragneva-Lewers and Kataryna Wolczuk, 'The Eurasian Economic Union: Deals, Rules, and the Exercise of Power' (London: Chatham House, 2017).

26. Anadolu Agency, 'Russia Disputes with Armenia, Belarus on Gas Prices', 19 May 2020. https://www.aa.com.tr/en/economy/russia-disputeswith-armenia-belarus-on-gas-prices/1846465. Accessed 15 September 2020.

27. Samuel Stolton, 'Armenia's EU Accession Could Be a "Question for the People"', 15 October 2019. https://www.euractiv.com/section/arm enia/news/armenias-eu-accession-could-be-a-question-for-the-peopledeputy-pm-says/. Accessed 14 September 2020.

28. Azimzhan Khitakhumnov and Bulat Mukhamediyev, 'Eurasian Economic Union: Present and Future Perspectives', Economic Change and Restructuring 50 (2017): 59-77.

29. European Union, 'The European Union and the Russian Federation', 25 February 2020. https://eeas.europa.eu/headquarters/headquarters-hom epage/35939/european-union-and-russian-federation_en. Accessed 11 November 2020.

30. Tatiana Isachenko, 'The European Context of Russian Trade Policy', in Russian Trade Policy, Achievements, Challenges and Prospects, eds. Sergei Sutryn, Olga Y. Trofimenko and Alexandra Koval (London: Routledge, 2019), 165-80.

31. EFTA, 'Russia/Belarus/Kazakhstan. Negotiations Currently on Hold', n.d. https://www.efta.int/free-trade/ongoing-negotiations-talks/russiabelarus-kazakhstan. Accessed 15 September 2020.

32. United States Department of Agriculture, Foreign Agricultural Service, 'Retail Foods', GAIN Report RS2020-0036, 6 August 2020. https:// apps.fas.usda.gov/newgainapi/api/Report/DownloadReportByFileN ame?fileName=Retail\%20Foods_Moscow\%20ATO_Russian\%20Federat ion_06-30-2020. Accessed 6 November 2020. 
33. Rilka Dragneva-Lewers and Kataryna Wolczuk, 'Trade and Geopolitics: Should the EU Engage with the Eurasian Economic Union?', European Policy Centre Policy Brief, 2 April 2015. https://css.ethz.ch/en/ser vices/digital-library/publications/publication.html/189983. Accessed 5 September 2020.

34. Ksenia S. Volnistaya, 'Five Years of the Eurasian Economic UnionResults and New Benchmarks for Belarus', 2019. https://elib.bsu.by/ bitstream/123456789/221587/1/81-85.pdf. Accessed 12 September 2020.

35. United States Department of Agriculture, Foreign Agricultural Service, 'Eurasian Economic Commission Published 2021 TRQs', GAIN Report no. RS2020-0041, 28 August 2020. www.fas.usda.gov/data. Accessed 12 November 2020.

36. Eurasian Economic Commission, 'Agroindustrial Policy of the Eurasian Economic Union', 2015, 4. http://www.eurasiancommission.org/ru/ Documents/APK_ing_n.pdf. Accessed 7 November 2020.

37. Eurasian Economic Commission, 'EEC and Minselkhoz of Russia Discussed Prospects for Developing Integration in Agricultural Sector', 19 August 2020. http://www.eurasiancommission.org/en/nae/news/ Pages/19.08.2020-1.aspx. Accessed 6 November 2020.

38. Eurasian Economic Commission, 'EAEU Agriculture Ministers Discussed Food Security in Conditions of Coronavirus Pandemic', 19 May 2020. http://www.eurasiancommission.org/en/nae/news/Pages/19-05-20201.aspx. Accessed 16 September 2020.

39. Vladimir Mazyrin, 'The Impact of the EAEU-Vietnam FTA on Bilateral Trade', 25 March 2019. http://greater-europe.org/archives/6636. Accessed 16 September 2020.

40. Parlamentaskaia gazeta, 'Soglashenie o svobodnoi torgovle mezhdu EAES i Serbiei rassmotriat senstory', 4 November 2020. https://kvedom osti.ru/news/https-www-pnp-ru-economics-soglashenie-o-svobodnoy-tor govle-mezhdu-eaes-i-serbiey-rassmotryat-senatory-html.html. Accessed 4 November 2020.

41. TASS, 'Iran i EAES mogut sozdat' postoiannuiu zonu svobodnoi torgovli do kontsa goda', 2 November 2020. https://www.dairynews.ru/news/ iran-i-eaes-mogut-sozdat-postoyannuyu-zonu-svobodn.html. Accessed 2 November 2020.

42. Fakhri Vakilov, 'Kazakhstan, Other EAEU Countries to Reduce Import Duties on Iran on 502 Goods', 26 April 2019. https://www.bilaterals. org/?kazakhstan-other-eaeu-countries-to. Accessed 7 November 2020.

43. Aljazeera America, 'Iran and Russia Closing in on Trade Agreement', 10 January 2014. http://america.aljazeera.com/articles/2014/1/ 10/sources-iran-andrussiaclosinginontradearrangement.html. Accessed 2 September 2020. 
44. Eurasian Economic Commission, 'Framework Agreement on Comprehensive Economic Cooperation Between the Eurasian Economic Union and Its Member States, of the One Part, and the Republic of Singapore, of the Other Part', October 2019. http://www.eurasiancommission. $\mathrm{org} / \mathrm{ru} / \mathrm{act} / \mathrm{trade} /$ dotp/sogl_torg/Documents/Сингапур/EAEU-Sin gapore\%20Framework\%20Agreement.pdf. Accessed 11 November 2020.

45. Bilaterals.org, 'EAEU-Singapore Free Trade Agreement Signed in Yerevan', l October 2019. https://www.bilaterals.org/?eaeu-singapore-freetrade. Accessed 11 November 2020.

46. Dmitrii Bokarev, 'FTZ with Singapore-A New Bridge Between EAEU and ASEAN', 23 January 2020. https://journal-neo.org/2020/01/23/ $\mathrm{ftz}$-with-singapore-a-new-bridge-between-eaeu-and-asean/. Accessed 16 September 2020.

47. Ekaterina Y. Arapova and Tatiana M. Isaschenko, 'Russian Trade Policy: Main Trends and Impact on Bilateral Trade Flows', International Journal of Economic Policy in Emerging Economies 12, no. 1 (2019): 26-48.

48. Yurii Sizov, 'EAEU i Izrail' gotoviatsia k zakliucheniiu soglasheniia o zone svobodnoi torgovli', 3 July 2020. https://rg.ru/2020/07/03/ eaes-i-izrail-gotoviatsia-k-zakliucheniiu-soglasheniia-o-zone-svobodnoj-tor govli.html. Accessed 21 August 2020.

49. Israel Ministry of Foreign Affairs, 'PM Netanyahu Meets with Russian President Vladimir Putin in Jerusalem', 23 January 2020. https:// mfa.gov.il/MFA/AboutTheMinistry/Conferences-Seminars/World_Hol ocaust_Forum_2020/Pages/PM-Netanyahu-meets-with-Russian-Presid ent-Vladimir-Putin-in-Jerusalem--23-January-2020.aspx. Accessed 11 November 2020.

50. TASS, 'Rossiia poluchila pravo postavki molochnoi i rybnoi produktsii $\mathrm{v}$ Egipet', 13 November 2020. https://kvedomosti.ru/news/https-tass-ruekonomika-9981907.html. Accessed 13 November 2020.

51. The EAEU reported that in 2014 the top consumers of its food products were CIS countries (20.3\%), EU countries (14.8\%), Turkey (12.6\%), Egypt (7.2\%) and China (6.3\%). Also, Iran (5.2\%) and Korea (4.7\%) were important consumer of food from EAEU countries. Eurasian Economic Commission, 'Agroindustrial Policy of the Eurasian Economic Union', 49-50.

52. Italian Food News Net, 'Italian Food Exports to Russia Have Lost 1 bn Euro', 6 August 2019. https://news.italianfood.net/2019/08/06/ italian-food-exports-to-russia-have-lost-1-bn-euro/. Accessed 5 October 2020.

53. Ekaterina Shokurova, 'Pravitel'stvennaia komissiia podderzhala sozdanie gossistemy proslezhivaieosti zerna', 12 November 2020. https://www. agroinvestor.ru/analytics/news/34788-pravitelstvennaya-komissiya-pod 
derzhala-sozdanie-gossistemy-proslezhivaemosti-zerna/. Accessed November 2020.

54. Vienna Institute for International Economic Studies, 'Trade Reorientation in Russia: Will China Replace the EU?', 10 July 2018. https://wiiw. ac.at/trade-reorientation-in-russia-will-china-replace-the-eu--n-327.html. Accessed 2 September 2020.

55. Kvedomosti.ru, 'Kitai i Rossiia podpishut document o merakh po uvelicheniiu tovarooborota do \$200 mlrd', 10 September 2019. https:// kvedomosti.ru/news/kitaj-i-rossiya-podpishut-dokument-o-merax-pouvelicheniyu-tovarooborota-do-200-mlrd.html. Accessed 12 November 2020.

56. Inna Ganenko, 'Terra inkognita dlia Rossiiskogo agroexporta', Agroinvestor, no. 5 (May 2019): 19.

57. The Dairy News, 'Eksport Rossiiskoi produktsii APK v Kitai vyros na 24\%', 6 November 2020. https://www.dairynews.ru/news/eksportrossiyskoy-produktsii-apk-v-kitay-vyros-nal l.html. Accessed 6 November 2020.

58. See Anatoly Medetsky, 'Russia's Newest Ambition in China Is Selling More Chicken Wings', 22 May 2019. https://www.bloomberg.com/ news/articles/2019-05-22/russia-s-newest-ambition-in-china-is-sellingmore-chicken-wings. Accessed 12 November, 2020; and Sin'khua, 'Sotrudnichestvo $\mathrm{v}$ oblasti APK-novaia tochka rosta $\mathrm{v}$ torgovoekonomicheskom vzaimodeistvii Rossii i Kitaia', 27 November 2019. https://agrovesti.net/news/indst/sotrudnichestvo-v-oblasti-apk-novayatochka-rosta-v-torgovo-ekonomicheskom-vzaimodejstvii-rossii-i-kitaya. html. Accessed 13 November 2020.

59. Economist Intelligence Unit, The Chinese Consumer in 2030 (London: Economist Intelligence Unit, 2016).

60. These authors use an expansive definition for China's middle class that encompasses not only income but also education and occupation. See Celine Bonnefond, Matthieu Clement, and Francois Combarnous, 'In Search of the Elusive Chinese Urban Middle Class: An Exploratory Analysis', Post-Communist Economies 27, no. 1 (2015): 41-59.

61. Fred Gale, James Hansen, and Michael Jewison, 'China's Growing Demand for Agricultural Imports', Economic Research Service Bulletin, no. 136 (February 2015): 3-4.

62. Kamron Daugherty and Hi Jiang, 'Outlook for U.S. Agricultural Trade', Economic Research Service Situation and Outlook Report AES-108 (30 May 2019): 5. The value of U.S. agricultural exports to China decreased as a result of the trade war between the two countries, to about $\$ 24$ billion USD in 2017 and to only $\$ 9.3$ billion USD in 2018.

63. Reuters, 'China's Pork Imports May Hit Record 4.6 Million Tonnes in 2020: Rabobank', 8 November 2019. https://www.reuters.com/art 
icle/us-china-swinefever-pork-imports/chinas-pork-imports-may-hit-rec ord-4-6-million-tonnes-in-2020-rabobank-idUSKBNIXI0ZI. Accessed 13 November 2020.

64. Ministerstvo sel'skogo khoziaistva Rossiiskoi Federatsii, National'nyi doklad: $O$ khode $i$ resul'tatakh realizatsii v 2010 godu gosudarstvennoi programmy razvitiia sel'skogo khozyaistva $i$ regulirovaniia rynkov sel'skokhoziaistvennoi produktsii, syr'ia $i$ prodovol'stviia na 2008-2012 (Moscow: Ministry of Agriculture, 2011), 42-3; and Ministerstvo sel'skogo khoziaistva Rossiiskoi Federatsii, National'nyi doklad: O khode $i$ resul'tatakh realizatsii v 2018 godu gosudarstvennoi programmy razvitiia sel'skogo khozyaistva $i$ regulirovaniia rynkov sel'skokhoziaistvennoi produktsii, syr'ia $i$ prodovol'stviia na 2013-2020 (Moscow: Ministry of Agriculture, 2019), 54.

65. Liubov Savkina, 'Kogda svinina poedet v Kitai', Agroinvestor, no. 2 (February 2020): 39-40.

66. Ibid., 40 .

67. United States Department of Agriculture, Foreign Agricultural Service, 'Oilseeds and Production Annual', GAIN Report RS2020-0023, 27 April 2020. www.fas.usda.gov/data. Accessed 13 November 2020.

68. Author's calculations based on data from World Integrated Trade Solutions by the World Bank, https://wits.worldbank.org. The category of agricultural products is the sum total of «Animal» (HS01, 02, 03, 04 and 05), «Vegetables» (HS06, 07, 08, 09, 10, 11, 12, 13, 14 and 15, and «Food Products» (HS16, 17, 18, 19, 20, 21, 22, 23 and 24).

69. Author's calculations based on data from World Integrated Trade Solutions by the World Bank, https://wits.worldbank.org. The category of agricultural products is the sum total of Animal (HSOl, 02, 03, 04 and 05), Vegetables (HS06, 07, 08, 09, 10, 11, 12, 13, 14 and 15, and Food Products (HS16, 17, 18, 19, 20, 21, 22, 23 and 24).

70. Dragneva-Lewers and Wolczuk, 'Trade and Geopolitics: Should the EU Engage with the Eurasian Economic Union?'.

\section{Selected Bibliography}

Arapova, Ekaterina and Tatiana Isachenko. 'Russian Trade Policy: Main Trends and Impact on Bilateral Trade Flows'. International Journal. of Economic Policy in Emerging Economies 12, no. 1 (2019): 26-48.

Baldwin, Richard E. 'Multilateralising Regionalism: Spaghetti Bowls as Building Blocks on the Path to Global Free Trade'. The World Economy 29 (2006): 1451-518. 
Bhagwati, Jagdish and Anne O. Krueger. 'US Trade Policy: The Infatuation with Free Trade Agreements'. In The Dangerous Drift to Preferential Trade Agreements. Washington, DC: AEI Press, 1995.

Brown, Andrew G. and Robert M. Stern. 'Free Trade Agreements and Governance of the Global Trading System'. The World Economy 34, no. 3 (2011): $331-54$.

Clapp, Jennifer. Food, 2nd ed. Cambridge, UK: Polity Press, 2016.

Clausing, Kimberly. 'The Progressive Case Against Protectionism'. Foreign Affairs 98, no. 6 (November-December 2019): 109-20.

Davis, Christina L. Food Fights Over Free Trade. Princeton: Princeton University Press, 2003.

Dragneva-Lewers, Rilka and Kataryna Wolczuk. 'The Eurasian Economic Union: Deals, Rules, and the Exercise of Power'. London: Chatham House, 2017.

Elliott, Kimberly Ann. Delivering on Doha: Farm Trade and the Poor. Washington, DC: Institute for International Economics, 2006.

Hofmann, Claudia, Alberto Osnago and Michele Ruta. 'The Content of Preferential Trade Agreements'. World Trade Review 18, no. 3 (2018): 365-98.

Isachenko, Tatiana. 'The trade policy of Russia: Latest Developments and Main Priorities'. Rivista di Studi Politici Internazionali 80, no. 3 (2013): 347-60.

Isachenko, Tatiana. 'The European Context of Russian Trade Policy'. In Russian Trade Policy. Achievements, Challenges and Prospects, eds. Sergei Sutyrin, Olga Y. Trofimenko, and Alexandra Koval. London: Routledge, 2019, 165-80.

Josling, Timothy and Stefan Tangermann. Transatlantic Food and Agricultural Trade Policy: 50 Years of Conflict and Convergence. Cheltenham, UK and Northampton, MA: Edward Elgar Publishing, 2015.

Khitakhumnov, Azimzhan and Bulat Mukhamediyev. 'Eurasian Economic Union: Present and Future Perspectives'. Economic Change and Restructuring 50 (2017): 59-77.

Libman, Alexander and Evgeny Vinokurov. Holding-Together Regionalism: Twenty Years of Post-Soviet Integration. London: Palgrave Macmillan, 2012.

McGovern, Edmond. International Trade Regulation. Exeter, UK: Globefield Press, 2008.

Putnam, Robert. D. 'Diplomacy and Domestic Politics: The Logic of Two-Level Games'. International Organization 42, no. 3 (1988): 427-60.

Rau, V. V. 'Russia in the Customs Union: The Agrarian Aspect'. Studies on Russian Economic Development 24, no. 1 (2013): 77-83.

Verdiyeva, Seljan, 'The Eurasian Economic Union: Problems and Prospects'. The Journal of World Investment and Trade 19, no. 4 (2018): 722-49.

Wegren, Stephen K. and Christel Elvestad. 'Russia's Food Self-sufficiency and Food Security: An Assessment'. Post-Communist Economies 30, no. 5 (2018): $565-87$. 
Open Access This chapter is licensed under the terms of the Creative Commons Attribution 4.0 International License (http://creativecommons.org/licenses/ by $/ 4.0 /$ ), which permits use, sharing, adaptation, distribution and reproduction in any medium or format, as long as you give appropriate credit to the original author(s) and the source, provide a link to the Creative Commons license and indicate if changes were made.

The images or other third party material in this chapter are included in the chapter's Creative Commons license, unless indicated otherwise in a credit line to the material. If material is not included in the chapter's Creative Commons license and your intended use is not permitted by statutory regulation or exceeds the permitted use, you will need to obtain permission directly from the copyright holder.

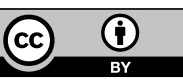

